\title{
Cross-shore Mysidacea (Crustacea) distribution in two sandy beaches with contrasting morphodynamics
}

\author{
Carlos A. Borzone 1; Luciano Lorenzi ${ }^{2} \&$ Patrícia Calil ${ }^{3}$ \\ ${ }^{1}$ Centro de Estudos do Mar, Universidade Federal do Paraná. Caixa Postal 50002, 3255-000 Pontal do Paraná, Paraná, Brasil. \\ ${ }^{2}$ Laboratório de Bentos, Universidade da Região de Joinville. Caixa Postal 1005, 89240-000 São Francisco do Sul, Santa \\ Catarina, Brasil. \\ 3 Programa de Pós-Graduação em Zoologia, Departamento de Zoologia, Universidade Federal do Paraná. \\ Caixa Postal 19020, 81531-980 Curitiba, Paraná, Brasil.
}

\begin{abstract}
The order Mysidacea comprises small and very common crustaceans that inhabit most coastal ecosystem. The present contribution describes the composition, abundance and distribution of mysids in two sandy beaches representing the extreme conditions of the morphodynamics spectrum. Six species of mysids were found at the studied beaches. Metamysidopsis neritica Bond-Buckup \& Tavares, 1992 was the most abundant species with more than $97 \%$ of the total individuals collected at the two beaches. At the dissipative beach was dominant in the swash and surf zone, with the greater abundance in the inner surf zone. At the reflective beach, this species was extremely abundant in the surf zone and backward the breaker. Bowmaniella brasiliensis Bacescu, 1968 occurred in low density at the surf zone of the dissipative beach, with the greater abundance in the outer surf zone, and it was practically absent in the nearshore zone. We suggest that mysids zonation in sandy beaches may be first developed as a response to food availability patterns imposed by the nearshore circulation systems, and in the second place as a result of competitive exclusion. The suggestion of partitioning of food and spatial resources shown by the mysid species is surprising in view of the apparent physical harshness and low spatial heterogeneity that seem to characterise the beach environment.

KEY WORDS. Opossum shrimps; sandy bottom; spatial distribution; surf zone.
\end{abstract}

RESUMO. Distribuição dos Myscidacea (Crustácea) em duas praias arenosas com diferente morfodinamismo. A ordem Mysidacea compreende um grupo de pequenos crustáceos muito comuns na maioria dos ecossistemas costeiros. A presente contribuição descreve a composição, abundância e distribuição dos misidáceos em duas praias arenosas representando as condições extremas do espectro morfodinâmico. Foram achadas seis espécies de misidáceos. A espécie mais abundante foi Metamysidopsis neritica Bond-Buckup \& Tavares, 1992, com mais de $97 \%$ do total dos indivíduos coletados nas duas praias. Na praia dissipativa, $M$. neritica foi dominante no espraiamento da onda e na zona de arrebentação, com as maiores abundâncias na arrebentação interna. Na praia refletiva esta espécie foi muito abundante na arrebentação e imediatamente atrás da mesma. Bowmaniella brasiliensis Bacescu, 1968 esteve presente em baixas densidades na zona de arrebentação da praia dissipativa, com as maiores abundancias na arrebentação externa e praticamente ausente nas águas rasas por trás da arrebentação. Sugerimos que a zonação de misidáceos em praias arenosas foi primeiramente desenvolvida como resposta à disponibilidade de alimento determinada pelo padrão de correntes de circulação e, secundariamente, como resultado de exclusão competitiva. Resulta surpreendente o fato das espécies de misidáceos dividirem recursos espaciais e de alimentação num ambiente de praia arenosa que é geralmente caracterizado como de baixa heterogeneidade espacial e submetido a um forte estresse físico.

PALAVRAS-CHAVE. Camarões misidáceos; fundos arenosos; distribuição espacial; zona de arrebentação.

The order Mysidacea comprises small and very common crustaceans that inhabit most coastal ecosystems. As other peracaridans, adult females are provided with a marsupium between pairs of pereopods and keep their embryos in it until they grow to juveniles. They are also known as opossum shrimps as well as mysids (Murano 1999).

Although present in different habitats, as sandy bottoms of estuaries and coastal shelf, rocky shores and Laminaria beds 
(Pezzack \& Corey 1979), early works on sandy beach ecology remarks the importance of mysids as components of the sandy beach ecosystem. A pioneer study by CLuTTER (1967) showed that mysids form schools and occupy clear zones throughout the sandy nearshore, occurring on or near the bottom. Other studies showed that most species are burrowed in the uppermost centimetres of sand during the day (Moran 1971). For these reasons many authors deal with these organisms as being bentho-pelagic or epibenthic organisms (Allen 1984). During night, they migrate to the water column to eat, mate or liberate brooded offspring (TAKAHASHI \& KAWAGUCHI 1995, 1997).

They are very abundant in Brazilian waters, however few works related to taxonomy (Costa 1964, Almeida Prado 1974, Tavares \& Bond-Buckup 1991, Murano 1999), reproduction (Loureiro-Fernandes \& Gama 1996, Gama \& Zamboni 1999, Gama et al. 2002) and ecology (Rorig et al. 1997) were done.

Recent studies on faunal of sandy beaches fauna were strongly influenced by the new morphodynamic concept of beach classification developed by SHORT \& WRight (1983). A simple formulation including beach profile, sediment grain characteristics, and height and period of waves acting on the shoreline, allowed a more objective and complete description of the dynamics of the beach environment (SHORT 1996). In accordance to this concept, beaches can be enclosed between two extreme conditions: reflective, characterised by a steep and narrow profile, usually composed of coarser sand and surge/collapsing beaker types, and dissipative, characterised by a wide and gentle profile, generally composed of fine sand and spilling beakers. Starting from this classification, hypothetical relationship between morphodynamics beach state and composition and zonation patterns of macrobenthic communities (JARAMILLO et al. 1993, Borzone et al. 1996, Gimenez \& Yannicelli 1997) as well as species populations characteristics (Borzone et al. 1998, Veloso $\&$ CARDoso 2001), were analysed. The present contribution describe, for the first time, the composition, abundances and distribution of mysids in two sandy beaches representing the extreme conditions of the morphodynamics spectrum.

\section{MATERIAL AND METHODS}

Two beaches of the Paraná Coast $\left(25^{\circ} 20-26^{\prime} \mathrm{S}, 48^{\circ} 05-36^{\prime} \mathrm{W}\right)$, south Brazil, were selected for this study. Atami Beach is an open to the ocean beach southern Paranaguá Bay inlet. It has an intertidal gentle slope with fine to very fine sand, a wide (50 to $200 \mathrm{~m}$ ) surf zone and a modal dissipative morphodynamics stage ( $\Omega=7.5, \Sigma=228$, sensu Wrigth et al. 1979) (Borzone \& Souza 1997, SoAres et al. 1997). Mansa Beach is a more protected beach northern Guaratuba Bay. It has a steep and stable intertidal profile with medium sand and well formed beach cusps, a narrow surf zone with plunging waves breaking directly on the beach face, and a typical reflective morphodynamic stage all over the year $(\Omega=1.7, \Sigma=3.8$, sensu Wrigth et al. 1979) (BARros et al. 2001). Daylight-samples were obtained on March $3^{\text {th }}$ (Atami Beach) and March $27^{\text {th }}$ (Mansa Beach) 2001, during spring low tide. Six sample stations were distributed across shore at Atami Beach, A1 in the swash zone, A2-A3 in the surf zone and A4-A6 in the nearshore zone; and five sample stations at Mansa Beach, M1 in the swash zone, M2 in the surf zone, and M3-M5 in the nearshore zone (Fig. 1). An epibenthic dredge with a rectangular mouth of $30 \mathrm{x} 80 \mathrm{~cm}$ was used as sample device (ELEFTHERIou \& Holme 1984, Brandt \& Barthel 1995). A $250 \mathrm{~cm}$ long plankton net of $0,3 \mathrm{~mm}$ mesh size was attached to the top and lateral margin of the rectangular mouth. The bottom margin of the plankton net was sewed to a tickler chain of one inch thickness and another tickler chain was added to the mouth $10 \mathrm{~cm}$ in front to the later. These chains had the purpose to disturb the bottom in front of the net mouth. This device "catch" benthic species that are superficially burrowed into the sand, and hypopelagic species that remained $30 \mathrm{~cm}$ above the sea floor, indiscriminately. More than $90 \%$ of the pelagic mysids occurred within $30 \mathrm{~cm}$ of the sand bottom during the day (CLuTter 1967). Therefore, it can be assumed that this device sampled the total distributions of these species within the area.

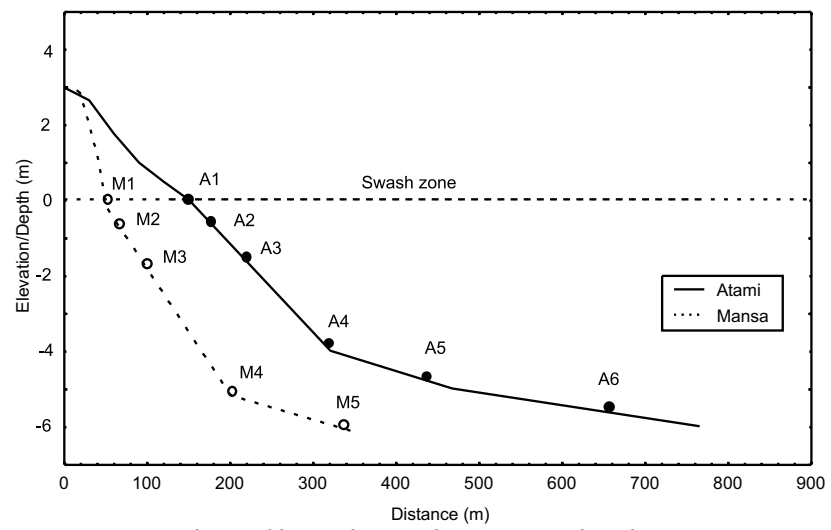

Figure 1. Beach profile and sample stations distribution at Atami and Mansa Beach.

At each sample station, the epibenthic dredge was pushed horizontally over the bottom and parallel to shore for $20 \mathrm{~m}$ $\left(\approx 4.8 \mathrm{~m}^{3}\right.$ of water) manually or with the aid of a boat. Three hauls were done at each station and later treated as replicates. Sediment samples were collected at each station for standard mechanical-sieving grain analysis. Statistical parameters were computed using the moments and moment measures (TANNER $1995)$ and the results expressed as $\phi$-values $\left(\phi=-\log _{2}\right.$ diameter in $\mathrm{mm}$ ). Calcium carbonate and organic matter content were determined as the loss in weight of dried sediment after treatment with hydrochloric acid and combustion $\left(600^{\circ} \mathrm{C}\right.$, six hours), respectively. Bottom water temperature and salinity were also registered.

Univariate ANOVA was performed, previous log transformation of data when Cochran homogeneity of variances

Revista Brasileira de Zoologia 24 (4): 943-949, dezembro 2007 
test was significant, to test significant differences on the abundance of the principal species of mysids between beaches and stations at each beach.

In order to compare the mysids composition of each sample at the two beaches, multidimensional scaling analyses (MDS) were conducted using a Bray-Curtis dissimilarity matrix obtained from square root transformed data of abundances (replicates were added). Analysis of similarities (ANOSIM) tests were used to determine the statistical significance of the samples group similarities (ClaRKE \& WARWICK 1994).

\section{RESULTS}

Sediment differences between beaches reflected their contrasting morphodynamics. At Atami beach we found fine sand onshore and very fine sand offshore, but with similar values of sorting, skewness and kurtosis along the transect (Tab. I). Calcium carbonates and organic matter increase offshore but returned to low values at the deeper station. At Mansa beach, grain size was coarser and only one station presented very fine sand. Sorting, skewness and kurtosis showed more variation between stations. Carbonates and organic matter had greater proportion in most of the sediments sampled in this beach. Temperature of bottom water was the same at the two beaches and salinity decrease offshore, notably at Mansa beach, indicating a greater estuarine influence at this reflective beach (Tab. I).

Six species of mysid were found at the studied beaches, Metamysidopsis neritica Bond-Buckup \& Tavares, 1992, Bowmaniella brasiliensis Bacescu, 1968, Mysidopsis coelhoi Bacescu, 1968, M. tortonesei Bacescu, 1968, Brasilomysis castroi Bacescu, 1968 and Promysis atlantica W.M. Tattersall, 1923. Metamysidopsis neritica was the most abundant species with 97.05 and $98.97 \%$ of the total individuals collected at Atami $\left(4,401\right.$ individuals $\left./ \mathrm{m}^{3}\right)$ and Mansa $\left(23,481\right.$ individuals $\left./ \mathrm{m}^{3}\right)$ beach, respectively (Tab. II). Bowmaniella brasiliensis, Mysidopsis coelhoi and Brasilomysis castroi occurred in both beaches, but in low abundance. Promysis atlantica and M. tortonesei were rare and found exclusively at Atami beach.

Mansa beach presented significantly greater abundance of Metamysidopsis neritica $(\mathrm{p}=0.017)$ and B. brasiliensis $(\mathrm{p}=$ $0.001)$. No significant differences were found on the abundance of Mysidopsis coelhoi between the two beaches ( $p=0.416)$.

Cross-shore distribution showed a particular pattern for both species and beaches. Metamysidopsis neritica at Atami beach was dominant in the swash and surf zone, with the greater abundance in the inner surf zone. At Mansa beach, this species was extremely abundant in the surf zone and backward the breaker. Bowmaniella brasiliensis occurred with low density at the surf zone of Atami beach, with the greater abundance in the outer surf zone, and was practically absent in the nearshore zone. On the other hand, at Mansa beach this species occurred at the nearshore zone with the greater abundance offshore. Mysidopsis coelhoi, as well as the other mysids species, occurred exclusively in the nearshore zone (Fig. 2, Tab. III).

MDS results were strongly influenced by Metamysidopsis neritica abundance. Inshore station of Mansa beach presented exclusive characteristic with very low abundance of this species at swash zone (M1) and very high abundance at surf zone and backward the breaker (M2 and M3). Intermediate abundance of M.neritica and Bowmaniella brasiliensis characterised a group of station of both beaches (swash and surf zone stations of Atami, A1, A2 and A3, and nearshore stations of Mansa, M4 and M5). Low abundance of M.neritica and the presence of other three species of mysids together characterised the nearshore stations of Atami beach (Fig. 3).

\section{DISCUSSION}

It is well know that benthic macrofauna in sandy beach are influenced by beach morphology, wave-action and sedi-

Table I. Sediment characteristics and bottom temperature and salinity of each sample station.

\begin{tabular}{|c|c|c|c|c|c|c|c|c|c|}
\hline & Mean $(\phi)$ & Sorting $(\phi)$ & Skewness $(\phi)$ & Kurtosis $(\phi)$ & Sand (\%) & $\mathrm{CO}_{3} \mathrm{Ca}(\%)$ & Organic Matter (\%) & Temperature $\left({ }^{\circ} \mathrm{C}\right)$ & Salinity \\
\hline \multicolumn{10}{|l|}{ Atami } \\
\hline $\mathrm{A} 1$ & 2.92 & 0.991 & 4.43 & 25.8 & 97.5 & 0.09 & 0.38 & 28 & 36 \\
\hline $\mathrm{A} 2$ & 2.82 & 0.845 & 4.47 & 31.5 & 98.5 & 0.09 & 0.39 & 28 & 36 \\
\hline $\mathrm{A} 3$ & 3.20 & 0.902 & 5.14 & 30.5 & 97.5 & 5.22 & 2.34 & 28 & 36 \\
\hline A4 & 3.16 & 0.910 & 5.09 & 30.2 & 97.5 & 1.37 & 1.14 & 28 & 35 \\
\hline A5 & 3.29 & 0.881 & 5.21 & 31.1 & 97.5 & 1.97 & 1.74 & 28 & 35 \\
\hline A6 & 3.23 & 0.895 & 5.17 & 30.8 & 97.5 & 0.49 & 0.77 & 28 & 35 \\
\hline \multicolumn{10}{|c|}{ Mansa } \\
\hline M1 & 2.35 & 1.098 & 0.64 & 7.5 & 96.5 & 7.02 & 1.48 & 28 & 37 \\
\hline M2 & 2.51 & 1.023 & 0.13 & 8.5 & 98.3 & 7.80 & 2.40 & 28 & 37 \\
\hline M3 & 2.99 & 0.683 & 5.08 & 44.6 & 97.9 & 4.48 & 1.48 & 28 & 35 \\
\hline M4 & 3.25 & 0.814 & 3.41 & 20.4 & 95.2 & 6.24 & 2.22 & 28 & 30 \\
\hline M5 & 2.65 & 1.345 & 1.90 & 8.7 & 93.3 & 4.48 & 1.29 & 28 & 30 \\
\hline
\end{tabular}



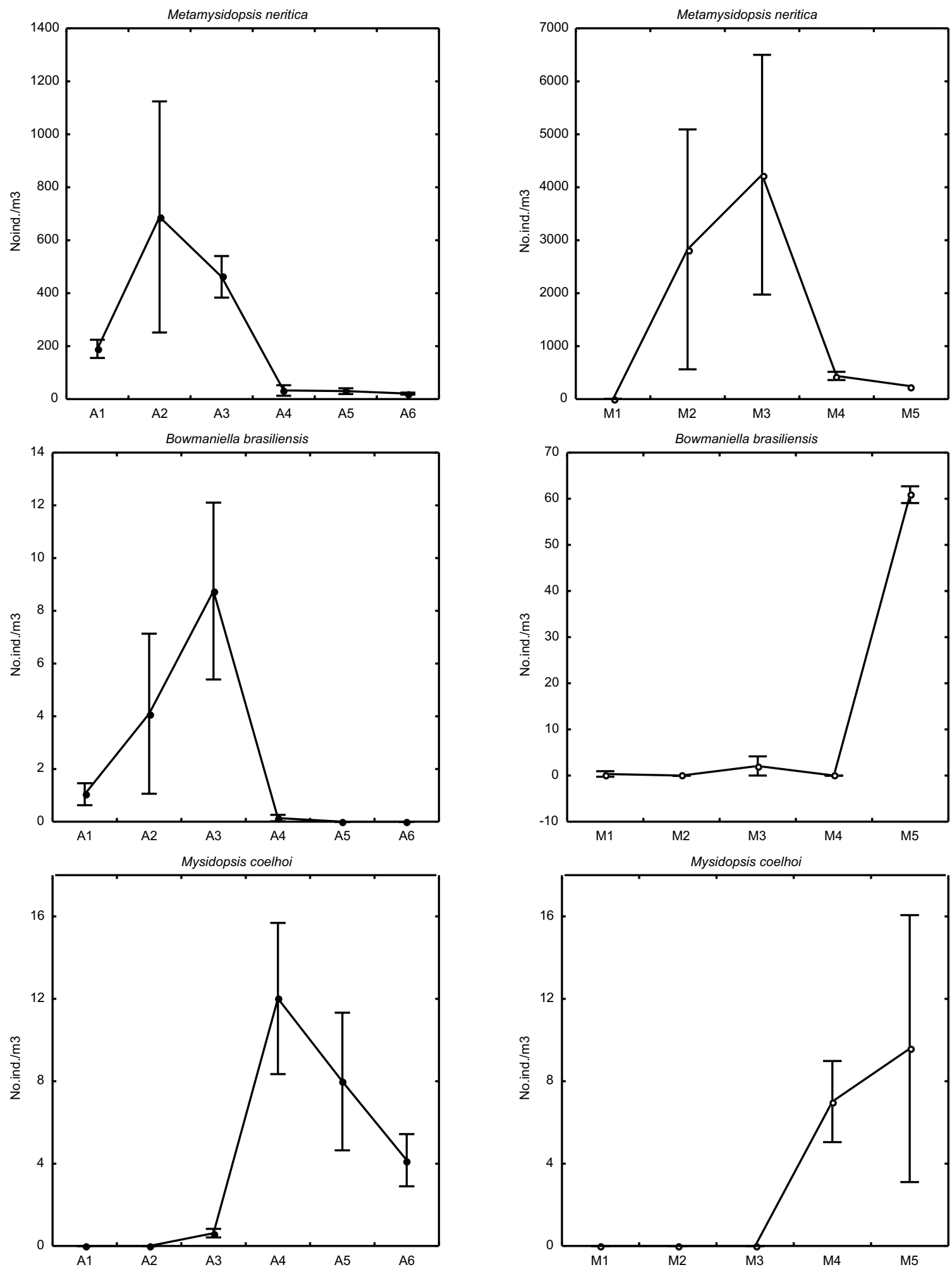

Figure 2. Mean abundance and standard deviation of three common mysid species along the beach profile of Atami Beach (A1 to A6) and Mansa Beach (M1 to M5). 
Table II. Abundance ( $\mathrm{n}^{\circ}$ individuals/m3) and proportion (\%) of each mysid species collected at Atami and Mansa Beach.

\begin{tabular}{|c|c|c|c|c|c|c|c|}
\hline & M. neritica & B. brasiliensis & M. coelhoi & B. castroi & P.atlantica & M. tortonesei & Total \\
\hline \multicolumn{8}{|l|}{ Atami } \\
\hline No. Ind. & 4,271 & 42 & 74 & 11 & 2 & 1 & 4,401 \\
\hline$\%$ & 97.05 & 0.95 & 1.68 & 0.25 & 0.04 & 0.03 & \\
\hline \multicolumn{8}{|l|}{ Mansa } \\
\hline No. ind. & 23,240 & 190 & 50 & 1 & 0 & 0 & 23,481 \\
\hline$\%$ & 98.97 & 0.81 & 0.21 & 0.01 & 0 & 0 & \\
\hline \multicolumn{8}{|l|}{ Total } \\
\hline No.ind. & 27,511 & 232 & 124 & 12 & 2 & 1 & 27,882 \\
\hline$\%$ & 98.67 & 0.83 & 0.44 & 0.04 & 0.01 & 0.01 & \\
\hline
\end{tabular}

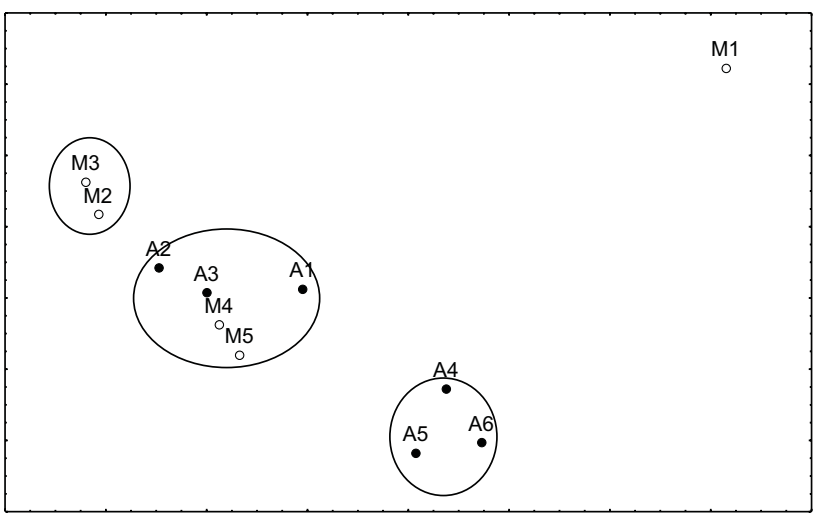

Figure 3. Multidimensional scaling analyses ordination (Stress 0.01) between sample stations. Circle indicates ANOSIM groups results $(p<0.05)$.

ments characteristics (McLachlan et al. 1993, Borzone et al. 1996). Therefore the structure of benthic macrofaunal assemblages have been generally considered to be related in particular ways to the type of the beach (BARRos et al. 2002).

Suprabenthic crustaceans have been recognised as common inhabitants of sandy beaches, where they are often highly abundant. These crustaceans are known to play an important role in nutrient regeneration in the surf zone and are also considered as a major food resource for some fishes and birds (LASIAK 1986, LasiaK \& McLachlan 1987). Results obtained by San Vicente \& Sorbe (1999) at Creixell beach, Tarragona, West Mediterranean, can be generalised to most sandy beaches, where suprabenthic crustaceans are resident species, mainly mysids, witch exhibited high densities and biomasses and usually a patchily distribution. Within the surf zone of Creixell beach, the main suprabenthic components showed a clear depth related zonation pattern as previously observed for mysids species in different beaches. For example, at La Jolla Bight, California, USA, Clutter (1967) found that only one mysid, Metamysidopsis elongata Clutter, 1966, constituted 87\% of the total sampled, and it distribution showed a maximum abun-
Table III. ANOVA results for cross-shore abundances of three mysids species at each beach $(n=3)$.

\begin{tabular}{lcc}
\hline & $\mathrm{p}$-level & Homogeneous Groups \\
\hline Atami & 0.001 & $\underline{231} \underline{546}$ \\
M. neritica & 0.001 & $\underline{32} \underline{1456}$ \\
$\begin{array}{l}\text { B. brasiliensis } \\
\text { M. coelhoi }\end{array}$ & 0.001 & $\underline{456} \underline{\underline{321}}$ \\
Mansa & & $\underline{32} \underline{451}$ \\
M. ner & 0.001 & $\underline{53} \underline{124}$ \\
B. brasiliensis & 0.001 & $\underline{5} \underline{\underline{4} 23}$ \\
M. coelhoi & 0.005 &
\end{tabular}

dance between 6 to 8 meters depth; studying the distribution of nineteen mysids at shallow waters of Florida, WigLey \& BuRNS (1971) found that two species were distributed only in the intertidal zone, five were typically shallow shelf inhabitants, and three resulted to be deep shelf and upper slopes species. Similar bathymetric zonation was found for Boreomysis species across the continental shelf (Hargreaves 1999).

At Paraná's beaches, farther on the morphodynamic beach type, the different species of mysid occupied clear zones roughly parallel to shore. Only one species, Metamysidopsis neritica, showed more than $95 \%$ of the total mysid abundance. At the dissipative beach this dominant species spread its distribution from the swash to the surf zone, but at the reflective beach, where presented its highest abundance, occurred immediately after the breakers. Bowmaniella brasiliensis, the larger species, presented a similar pattern of distribution between the beaches. At the dissipative beach occupied the surf zone, but with greatest abundance offshore, in the outer surf zone. At the reflective beach, where exhibited its highest abundance, occurred at the last station of the nearhsore zone. Other species occurred mainly in the nearshore zone of the dissipative beach.

These results disagree with CLUTTER (1967)'s observation at the La Jolla Bight, where the large species dominated inside the surf while the most abundant species, represented by 
Metamysidopsis elongata, peaked where rip currents disperses. Although M. neritica, the smaller Parana's species, occupied an onshore distribution, its absence in the reflective swash zone may be explained by the harsh swash climate and coarseness of the sediment of this extreme morphodynamic condition. However, its clear preferences for the surf zone at the dissipative beach together with its greatest abundance in the nearshore zone of the reflective beach indicated that other factors, besides morphodynamics, are controlling its distribution.

Mansa Beach receives more estuarine influences than Atami Beach, especially in deeper water, and salinity may be another factor controlling mysids distribution. In fact, many mysid are extremely abundant both in estuarine and nearshore marine waters. Wевв et al. (1997) investigate the osmoregulatory capacities of three mysids species that occur in clear zones along salinity gradients in estuaries along the south-east coast of South Africa and showed a well develop osmoregulation. In these species, salinity does not play a major role in establishing the spatial distribution patterns, and others factors, such as water depth, predation, food availability and substrate type seems to be more important.

Mysids seem to prefer animal-matter as food, but stomach contents of those individuals collected in coastal environments are in most cases dominated by detritus (Murano 1999). In many beaches, circulation patterns determine the distribution of detritus and phytoplankton, and this may explain the nocturnal onshore migration observed in Mesopodopsis slabberi Van Beneden, 1861, in Algoa Bay, South Africa (Weвb \& Wooldridge 1990) as well as the patchy surf zone distribution of Metamysidopsis elongata in Navegantes, South Brazil (RoRig et al. 1997).

ClutTer (1967) investigated the causes and functions of the zonation of the dominant mysid species at La Jolla Bight, and suggested that zonation have developed in response to food availability patterns imposed by nearshore circulation systems. Mysid food (non motile material at least) recirculates in this area affected by rip currents. The particle slightly heavier than seawater carried outside the breaker zone by rip currents fall out where the rip currents disperse and slow down, accumulating outside the breaker. This accumulation may be greater in reflective morphodynamics extreme. Metamysidopsis elongata, the dominant species in ClutTer (1967) study, may have been zoned as observed mainly in response to the pattern of availability of food that was imposed by the nearshore circulation system. Therefore, food accumulation at the dissipative beach seem to be concentrated in the surf zone while at the reflective beach strong rip-currents dispose this passive food resource outside the breakers.

Zonation seemed to persist through the activities of the animals, and they were not carried passively by water currents (ClutTer op.cit.). When similar species exhibited different zonation, as was the case with Metamysidopsis neritica and Bowmaniella brasiliensis in this study, this fact can be interpreted to be a manifestation of competitive exclusion. The suggestion of partition- ing of food and spatial resources shown by species of mysids is surprising, in view of the apparent physical harshness and low spatial heterogeneity that characterised the beach environment.

\section{REFERENCES}

Allen, D.M. 1984. Population dynamics of the mysid shrimp Mysidopsis bigelowi W.M. Tattersall in a temperate estuary. Journal of Crustacean Biology 4 (1): 25-34.

Almeida Prado, M.S. 1974. Sistemática dos Mysidacea (Crustacea) na região de Cananéia. Boletim do Instituto Oceanográfico de São Paulo 23: 47-87.

Barros JR, F.C.R; C.A. Borzone \& S. Rosso. 2001. The Macroinfauna of six beaches near Guaratuba Bay, Southern Brazil. Brazilian Archives of Biology and Technology 44 (4): 351-364.

Barros, F.; A.J. Underwood \& M. Lindegarth. 2002. A preliminary analysis of the structure of benthic assemblages of surf zones on two morphodynamic types of beach. Journal of Marine Biological Association 82: 353-357.

Borzone, C.A. \& J.R.B. SouzA. 1997. Estrutura da macrofauna bentônica no supra, meso e infralitoral de uma praia arenosa do sul do Brasil. Oecologia Brasiliensis 3: 197-212.

Borzone, C.A.; J.R.B. SouzA \& A.G. SoAres. 1996. Morphodynamic influence on the structure of inter and subtidal macrofaunal communities of subtropical sandy beaches. Revista Chilena de Historia Natural 69: 565-577.

Borzone, C.A.; Y.A.G. Tavares \& F.C.R. Barros. 1998. Beach morphodynamics and distribution of Mellita quinquiesperforata (Leske, 1778) on sandy beaches of southern Brazil, p. 581-586. In: R. Moor \& M. TElford (Eds). Proceedings of $9^{\text {th }}$ International Echinoderm Conference, San Francisco, California, USA. Rotterdam, A.A. Baukema, 923p. [ISBN 9054109297]

Brandt, A. \& D. Barthel. 1995. An improved supra and epibenthic sledge for catching Peracarida (Crustacea, Malacostraca). Ophelia 43: 15-23.

Clarke, K.B. \& R.M. WARWICK. 1994. Change in marine communities: an approach to statistical analysis and interpretation. Bournemouth, Natural Environment Research Council, Bourne Press, 144p.

Clutter, R.I. 1967. Zonation of nearshore mysids. Ecology 48: 200-208.

Costa, H.R. 1964. Notas sobre os Mysidacea da Costa Brasileira. Boletim do Museu Nacional 247: 1-9.

Eleftheriou, A. \& N.A. Holme. 1984. Macrofauna techniques, p. 140-216. In: N.A. Home \& A.D. MCInTyRe (Eds). Methods for the study of marine benthos. Oxford, Blackwell Scientific, 440 .

Gama, A.M.S. \& A.J. Zamboni. 1999. Aspectos da biologia e do cultivo de Metamysidopsis elongata atlantica para uso em testes de toxicidade. Nauplius 7: 127-139.

Gama A.M.S; M.A. Montú \& L.F.M. Gusmão. 2002. Pos-marsupial life cycle and growth of Metamysidopsis elongata atlantica (Crustacea, Mysidacea, Mysidae) under laboratory condition. 
Iheringia, Série Zoologia, 92 (1): 77-83.

Gimenez, L. \& B. YANNICELLI. 1997. Variability of zonation patterns in temperate microtidal Uruguayan beaches with different morphodynamic types. Marine Ecology Progress Series 160: 197-207.

Hargreaves, P.M. 1999. The vertical distribution of micronektonic decapod and mysid crustaceans across the Goban Spur of the Porcupine Seabight. Sarsia 84: 1-18.

Jaramillo, E.; A. McLachlan \& P. Coetzee. 1993. Intertidal zonation patterns of macroinfauna over a range of exposed sandy beaches in south-central Chile.. Marine Ecology Progress Series 101: 105-118.

LASIAK, T.A. 1986. Juveniles, food and the surf zone habitat: implications for teleost nursery areas. South African Journal of Zoology 21 (1): 51-56.

LasiaK, T.A. \& A. MCLACHLAN. 1987. Opportunistic utilization of mysid shoals by surf zone teleosts. Marine Ecology Progress Series 37: 1-7.

Loureiro-Fernandes, L. \& A.M.S. Gama. 1996. Molting cycle in Metamysidopsis munda (Crustacea: Mysidacea). Nauplius, 4: 171-172.

Mclachlan, A.; E. Jaramillo; T.E. Donn \& F. Wessels. 1993. Sandy beach macrofauna communities and their control by the physical environment: A geographical comparison. Journal of Coastal Research 15: 27-38.

Moran, S. 1971. Ecology of distribution of the sand-dwelling mysid Gastrosaccus sanctus (Van Beneden, 1861) along the mediterranean sandy shore of Israel. Crustaceana 3: 357-361.

Murano, M. 1999. Mysidacea, p. 1099-1140. In: D. Boltovskoy (Ed). South Atlantic Zooplankton. Leiden, Backhuys Publishers, $705 p$.

Pezzack, D.S. \& S. Corey. 1979. The life history and distribution of Neomysis americana (Smith) (Crustacea, Mysidacea) in Passamaquoddy Bay. Canadian Journal of Zoology 57: 785793.

Rorig, L.R.; C. Resgalla Jr; P.R. Pezzuto; E. dos S. Alves, \& F. Morelli. 1997. Analise ecologica de um processo de acumulação da diatomacea Anaulus sp. na zona de arrebentação da praia de Navegantes (Santa Catarina, Brasil). Oecologia Brasiliensis 3: 29-43.

SAN Vicente, C. \& J.C. Sorbe. 1999. Spatio-temporal structure of the suprabenthic community from Creixell beach (western Mediterranean). Acta Oecologica 20 (4): 377-389.

SHORT, A.D. 1996. The role of wave height, period, slope, tide range and embaymentisation in beach classifications: a review. Revista Chilena de Historia Natural 69: 589-604.

Short, A.D. \& L.D. Wright. 1983. Physical variability of sandy beaches, p. 133-144. In: A. McLachlan \& T. Erasmus (Eds). Sandy beaches as ecosystems. The Hague, Junk, 757p.

SOARES, C.R.; C.A. Borzone \& J.R.B. SouzA. 1997. Variações morfológica e sedimentológicas ao longo de um ciclo anual numa praia arenosa no sul do Brasil. Oecologia Brasiliensis 3: 245-258.

TAKAHASHI, K. \& K. KAWAGUCHI. 1995. Inter- and intraspecific zonation in three species of sand burrowing mysids, Archaeomysis kokuboi, A. japonica and Iiella ohshimai, in Otsuchi Bay, northeaster Japan. Marine Ecology Progress Series 116: 7584.

Takahashi, K. \& K. KaWaguchi. 1997. Diel and tidal migrations of the sand-burrowing mysids, Archaeomysis kokuboi, A. japonica and Iiella ohshimai, in Otsuchi Bay, northeastern Japan. Marine Ecology Progress Series 148: 95-107.

TANnER, W.F. 1995. Environmental clastic granulometry. Tallahassee, Florida Geological Survey, Special Publication 40, 163p.

TAVAREs, L.M.G. \& G. Bond-Buckup. 1991. Os mysidacea da região litoranea e estuarina de Tramandai, RS, Brasil (Crustacea, Peracarida, Mysidacea). Revista Brasileira de Zoologia 7 (12): 47-57.

Veloso, V.G. \& R.S. Cardoso. 2001. Effect of morphodynamics on the spatial and temporal variation of macrofauna on three sandy b eaches, Rio de Janeiro State, Brazil. Journal of Marine Biological Association 81: 369-375.

Weвb, P. \& T.H. Wooldridge. 1990. Diel horizontal migration of Mesopodopsis slabberi (Crustacea, Mysidacea) in Algoa Bay, southern Africa. Marine Ecology Progress Series 62: 73-77.

WebB, P.; T.H. Wooldridge \& T. Schlacher. 1997. Osmoregulation and spatial distribution in four species of mysid shrimps. Comparative Biochemistry and Physiology 117A (4): 427431.

Wigley, R.L. \& B.R. Burns. 1971. Distribution and biology of mysids (Crustacea, Mysidacea) from the Atlantic Coast of the United States in the NMFS Woods Hole Collection. Fishery Bulletin 69 (4): 717-746.

Wright, L.D.; J. Chappell.; B.G. Thom; H.P. Bradshaw \& P. Cowell. 1979. Morphodynamics of reflective and dissipative beach and inshore systems, South-eastern Australia. Marine Geology 32: 105-140.

Received in 29.V.2007; accepted in 13.XI.2007. 